炎症巣に打ける肥満細胞の消長

福田純也*, 藤森一平 $* *$

\section{medical topics}

Changes of mast cells in the inflammatory foci

Junya Fukuda*, Ippei Fujimori**

昨年の本学会で, 慢性副鼻腔炎といらヒト炎症に特い ても, 肥満細胞が炎症の初期すなわち渗出期に活躍し, 後期すなわら修復期にみられる線維化になんらかの関与 をしていることを報告した 1 。 今回は，純粋な急性炎症 病巣に沶いて肥満細胞がどのよらな動きをみせるかる探 る目的で, 急性虫垂炎手術材料を用い, 炎症の比較的早 期を表現しているとみられる虫垂病巣に括汁る肥満細胞 の動向を病理形態学的に検討したので報告する。

\section{対象と方法}

急性虫垂炎 50 症例（ 5 ～83歳，男子18例，女子 32 例）. 組織型別では, カタル性虫垂炎19例 $(38 \%)$, 蜂巣織炎性 虫垂炎24例 $(48 \%)$, 壊疽性虫垂炎 7 例 $(14 \%)$. 対象症 例の切除虫垂について，10\%ホルマリン固定，日常業務 の際, 切りだされパラフィン包埋されたブロックから組 織切片を作成, HE 染色, トルイジンブルー染色を必要 に応じ各種特殊染色を施し, 光学曊微鏡的に観察した。 成 績

カタル性虫垂炎の病理所見は，粘膜表層上皮細胞の剶 離, 粘膜固有層の水腫, 好中球浸潤, 細血管内好中球増 加, ときにかなりの好酸球の出現, 粘膜下, 特にリンパ 様組織周辺, 䇗層, 漿膜下のリンパ腔あるいはリンパ管 の拡大, 芽中心の腫大, 芽中心細胞の崩壊, リンバ様組 織からのリンパ球の減少などであって, 虫垂粘膜におけ る洷出性炎症の存在を示していた（网1 A)，な拈，これ らの所見のみられない部を対照とした。トルイジンブル 一染色で肥満細胞の態度をみると, 粘膜问有層の炎症性 水腫の強い部ではほとんど脱顆粒の状態で，脱顆粒が著 明な場合明細胞ないし，空胞化細胞としてみられ相当丹 念な観察が必要であった（図1B）。粘膜下組織, 筋層, 漿膜下組織では異染性顆粒を有する肥満細胞が比較的容 易に見いだされた。, 以上，滲出性炎病紧のうち，炎症性 水腫の顕著な部では肥満細胞は脱顆粒し，この脱顆粘現 象は炎症性水腫と密接な関連があるとみられた。

つぎに蜂巣織炎症性虫垂炎の比較的程度の軽い症例を 選び観察した。虫垂壁全層にわたって好中球浸潤をはじ め渗出性炎症所見がみられ（図 $2 \mathrm{~A}$ ), 粘膜は破壊された 膿性渗出物が虫垂腔内へ噴出している像も認められた. これらの病栄の肥満細胞の態度は, 炎症性水腫の強い部 ではほとんど脱顆粒しているが，筋層や漿膜下組織の好 中球浸潤の著明な部では肥満細部は異染性顆粒を有して いるものが相当数みられた（図2B）.

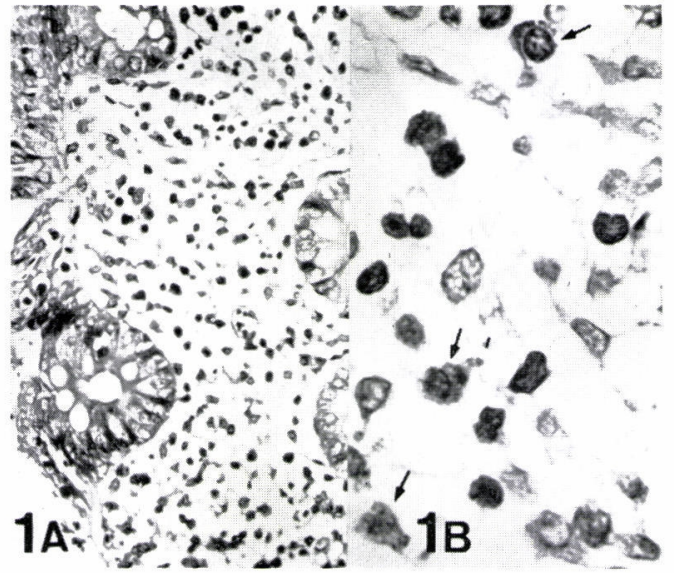

図 $1 \mathrm{~A}$ : 滲出性変化の頙著な虫垂粘膜 ( HE 染色, $\times 200)$ B: A の病等にみられた膜顆䊉した肥満細 胞（矢印）(トルイシンブルー染色, 油浸)

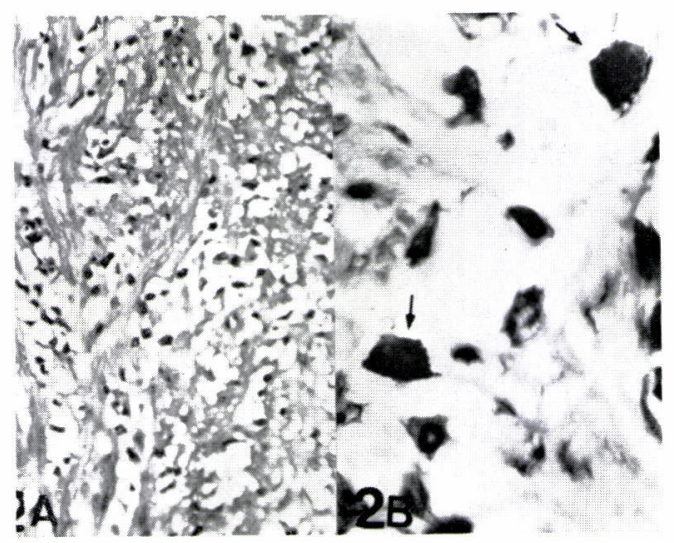

図 $2 \mathrm{~A}$ : 好中球浸潤の顕著な虫垂筋龧（HE 染色， $\times 200$ ）， B：A の病巣に攵られた異染性顆粒を有和 る肥満細胞(矢印)（トルイジンブルー染色，油浸）

考察

炎应反応は，起炎性刺激の種類，強さ，作用時間に左： 右されるとはい光, 細静脈を中心に炎症発来から連続的 に生起される血管反応が主軸をなし，血漿㝖出（炎症性 水腫之線維素析出), 好中球浸潤, 赤血球漏出の順注 行するものである。この炎症過程の早期において, 肥満 細胞が炎怔の初発时より炎怔性水腫の発現に閔与してい ることは，検索成績から十分らかがいらるところであっ たが，好中球浸潤と肥満細胞の脱顆粒との間に密接な関 与ありとはいえない成績であると考えられた。

\section{結 語}

急性虫垂炎手術材料を用い，资症過程の比較的早期を 表現しているとみられる虫垂滲出性病栄を検索し, 肥満 細胞の脱顆粒が炎怔性水腫と密接な関連を有しているこ とがうかがい知り，好中球浸潤巣には異染性顆粒を有す る細胞が相当数存在していることを明らかにした。

文献 1) 福田純也: 炎症栄に打计る肥満細胞 の消長。炎症 1(3): 391-396, 1981.

* Department of Pathology, 川崎市立川崎病院病理 部門, ** Department of Internal Medicine 同 内科 Kawasaki Muncipal Hospital 